\title{
Religião e performances corporais: etnografia com alunos evangélicos da zona rural de uma escola pública de Minas Gerais
}

SANDRA PEREIRA TOSTA

UNIVERSIDADE FEDERAL DE OURO PRETO (UFOP), OURO PRETO/MG, BRASIL HTTP://ORCID.ORG/0000-0002-4501-1008

WESLEI LOPES DA SILVA

REDE MUNICIPAL DE EDUCAÇÃO (RME) E UNIVERSIDADE ESTADUAL DE MINAS GERAIS (UEMG), ITAÚNA/MG, BRASIL HTTP://ORCID.ORG/0000-0002-1992-9851

LUCIMARA APARECIDA L. COSTA

SECRETARIA ESTADUAL DE EDUCAÇÃO DE MG (SEE) E SECRETARIA MUNICIPAL DE EDUCAÇÃO, CAPELINHA/MG, BRASIL HTTPS://ORCID.ORG/0000-0001-6255-9000

\section{Notas introdutórias}

A escola, como uma das instituições herdeiras do Iluminismo e uma das dimensões fundantes da modernidade, tornou-se, ao longo da história, uma das mais fortes expressões do sentido de urbanidade, uma vez que representou, no curso do desenvolvimento capitalista, a possibilidade de se alcançar a universalidade cultural, que é também uma dimensão da sociedade moderna. A escola possui, assim, por sua institucionalidade, uma historicidade geradora de uma cultura particular à qual todos precisam se submeter pelo bem da sua funcionalidade. Entre os seus sujeitos, os alunos são, certamente, os mais importantes. Sem eles não existe escola!

Diante disso, inúmeros estudos afirmam que nas escolas pouco se faz para possibilitar ao aluno ter espaços de interlocução, entre si e com os outros, a fim de apreender seus desejos, opiniões, preferências, críticas e sugestões. E identificam algumas razões para as dificuldades da escola em reconhecer seus 
alunos em sua condição cultural e social, e não apenas como aqueles que lá estão inseridos num contexto de organização e ritmo próprios, os quais, em geral, não abrem espaços para uma aproximação entre as autoridades e alteridades escolares. Evidenciaram-se, assim, problemas que vão desde a rotina escolar, que mantém os educadores na sala de aula quase todo o tempo, sem possibilitar que haja momentos de reflexão e discussão, até a ausência de um conhecimento mais amplo, de parte desses educadores, dos meninos e meninas com quem interagem cotidianamente.

A literatura em geral referencia que a escola, tal qual a conhecemos hoje, com suas regras, estrutura, valores e princípios, surgiu na Europa no século XVIII e se organizou nesse cenário histórico arcando em seu ideário com os valores da época. Sem dúvida, a escola, juntamente com a Igreja e a família, é considerada o espaço primeiro e prioritário para a formação, socialização e inserção social das novas gerações. Em outros termos, a escola nunca se encontrou sozinha nesse papel, outras instituições dividem com ela o locus educativo dos indivíduos.

Uma das características da evolução da escola, em geral, foi ter se organizado por um longo percurso rejeitando outras formas de convívio social e transmissão de conhecimentos que não espelhassem a reprodução do seu ethos cultural institucionalizado. Quando a escola não reconhece a existência de outros processos culturais e de aprendizagens, ela se fecha em si mesma. E o que resulta disso é o distanciamento da instituição com seu modus operandi da realidade do seu entorno. Esse entorno hoje não é mais local ou nacional, ampliou-se nos termos da mundialização, considerando que a sociedade se organiza numa rede mundial viabilizada pela emergência da tecnologia digital.

Fato é que essa escola, na cultura ocidental, historicamente ensimesmada em seus contextos pedagógicos, defronta-se, na contemporaneidade, com um âmbito muito mais complexo e contrário a um ideário fundador que pretendeu homogeneizar e uniformizar as condutas dos indivíduos de modo a integrá-los na ordem social. Nessa lógica a escola, na maioria das vezes, exerce o papel de apagamento das desigualdades, diferenças e diversidade histórico-culturais, agora amplamente visibilizadas em nível mundial, justamente por conta da chamada "sociedade em rede".

Contudo, e pelo próprio desenvolvimento histórico, por força das lutas sociais nas décadas de 1970 e 1980 e por conquistas na esfera jurídica, o processo de democratização da educação culminou com a promulgação da Constituição de 1988, referendada pela LDB n 9394/96. Os espaços e tempos escolares vão adquirindo outros contornos e passam a receber alunos de todas as camadas sociais, tornando a educação mais democrática. Tal fato vai se materializando por meio de políticas de universalização do acesso à educação básica implementadas, notadamente, a partir dos anos 2000.

Assim, as instituições escolares vivenciam conflitos rotineiros, os quais muitas vezes ocultam expressões etnocêntricas que desqualificam aqueles sujeitos oriundos da população pobre e historicamente excluída da escola. A escola se vê, assim, diante de muitos “outros” em suas alteridades e idiossincrasias, que habitualmente não eram encontrados; sobretudo no Ensino Médio e Superior, confrontam seus pressupostos políticos e pedagógicos.

E há que se reiterar: alunos, muito mais que estar nesta condição, são crianças, adolescentes, jovens, adultos e idosos que possuem experiências exteriores e anteriores à escola, constroem práticas e interagem com o mundo de formas variadas, tendo como base vivências e orientações como, por 
exemplo, trabalhadores, consumidores, internautas, filhas e filhos, mães e pais, negros, brancos, rural e urbanos, LGBTQIA+, rappers, sertanejos, católicos e evangélicos. Todas essas dimensões constituem esses sujeitos muito diversificados entre si, embora compartilhem características biofísicas típicas de quem está naquelas fases da vida.

Como se haver, por exemplo, com traços de alteridade como o pertencimento religioso cuja expressão simbólica de identidade se opõe a uma suposta homogeneidade requerida pela escola onde uma religião parece "dada", naturalizada em torno do ser católico? Nesse caso, são poucos os estudos que abordam as denominações não católicas na escola, notadamente em se tratando de alunos adolescentes e jovens rurais, em suas expressões corporais, cuja produção se articula às rotinas escolares, especificamente às aulas de Educação Física.

Pois bem, estamos falando de interações e conflitos de alunos e alunas na Escola Estadual de Ribeirão da Folha (EEDRF) localizada no distrito homônimo, na zona rural do Vale do Jequitinhonha, região nordeste do estado de Minas Gerais (que, além de Ribeirão da Folha, conta com duas comunidades: Córrego das Mangabeiras e Córrego das Cabeceiras). O pertencimento religioso autodeclarado dos estudantes é pela Igreja Evangélica Assembleia de Deus (IEAD) ${ }^{1}$, e suas performances em aulas de Educação Física e em outros tempos e espaços escolares. Nestas, o corpo em movimento se produz e é produzido como um elemento central nos exercícios, nos contatos diretos com professores e colegas, nos jogos pautados por alianças e disputas. De corpos forjados nas culturas e tensionados pelas implicações doutrinárias daquela denominação religiosa.

\section{Imagem 1: Localização da Comunidade de Ribeirão da Folha no Município de Minas Novas-MG.}

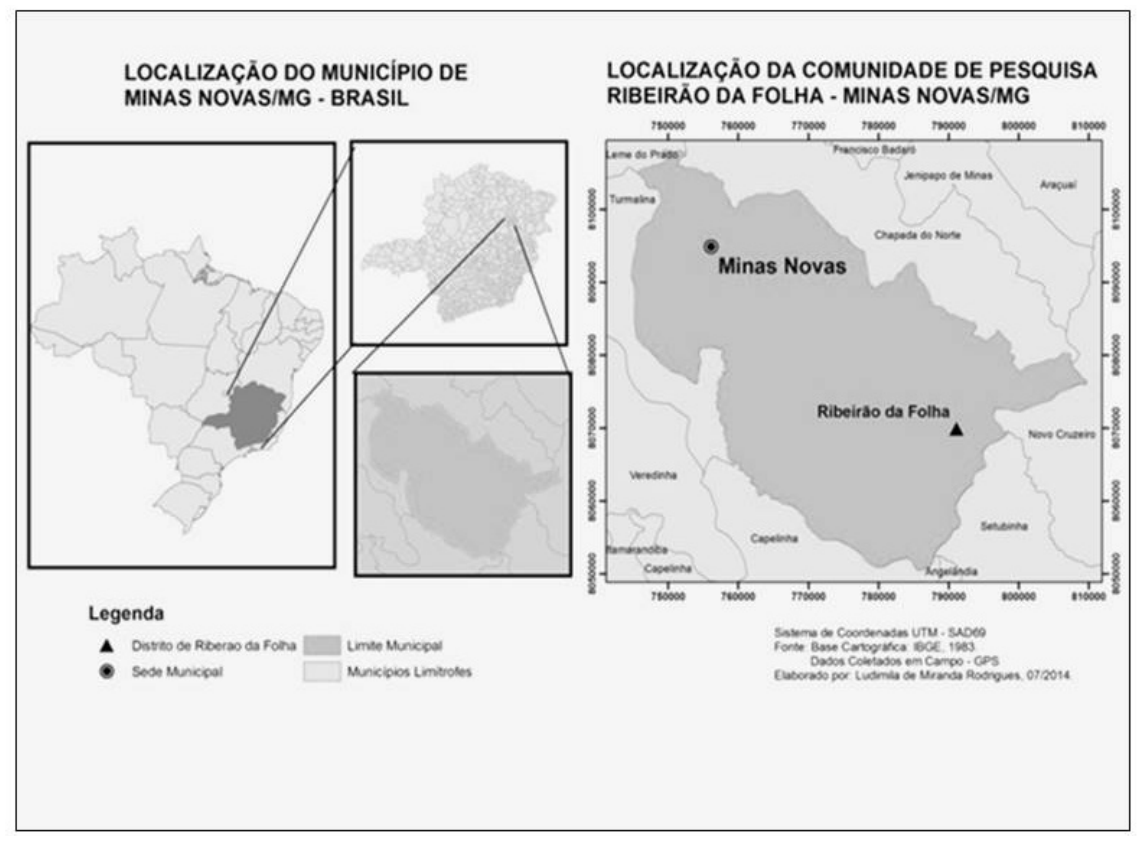

Fonte: Acervo da pesquisa.

$1 \mathrm{O}$ campo religioso tem passado por alterações desde os últimos anos do século XX com o crescimento das denominações evangélicas. Se até meados da década de 1980 o catolicismo era a religião majoritária no Brasil, o censo de 2010 apurou: católicos caíram para 64,6\%; evangélicos já eram 22,2\%. Em 2000, 15,4\% se disseram evangélicos; em 1991, o percentual de evangélicos era de 9\% e, em 1980, de 6,6\%. 
A Assembleia de Deus é a primeira igreja tradicional evangélica instalada no distrito de Ribeirão da Folha, e congrega a maioria dos alunos não católicos da escola pesquisada, conforme levantamento exploratório feito em 2014.

Quadro 1: Religiões em Minas Novas (MG).

\begin{tabular}{|l|l|l|}
\hline Religiões & $\begin{array}{l}\text { Quantidade de } \\
\text { pessoas }\end{array}$ & Porcentagem \\
\hline Católica Apostólica Romana & 25.056 & $81,37 \%$ \\
\hline Católica Apostólica Brasileira & 2.198 & $7,14 \%$ \\
\hline Evangélicos de origem Pentecostal -Igreja Assembleia de Deus & 787 & $2,56 \%$ \\
\hline Evangélica não determinada & 540 & $1,75 \%$ \\
\hline Evangélicos de origem Pentecostal -Igreja Congregação Cristã do Brasil & 482 & $1,57 \%$ \\
\hline Evangélicos de origem Pentecostal - Outras & & $1,07 \%$ \\
\hline Evangélicas de missão - Igreja Evangélica Batista & 328 & $0,98 \%$ \\
\hline Sem religião - Sem religião & 302 & $0,97 \%$ \\
\hline Outras religiosidades cristãs & 298 & $0,89 \%$ \\
\hline Evangélicos de origem Pentecostal -Igreja Deus é amor & 273 & $0,65 \%$ \\
\hline Evangélicos de origem Pentecostal -Igreja Universal do Reino de Deus & 201 & $0,44 \%$ \\
\hline Testemunhas de Jeová & 136 & \\
\hline Espírita & 66 & $0,21 \%$ \\
\hline Não determinada e múltiplo pertencimento & 42 & $0,14 \%$ \\
\hline Evangélicos de origem Pentecostal - Igreja Evangelho Quadrangular & 21 & 19 \\
\hline Umbanda e candomblé & & $0,07 \%$ \\
\hline Sem religião-Ateu & 16 & $0,06 \%$ \\
\hline Evangélicos de origem Pentecostal - Igreja Maranata & 15 & $0,05 \%$ \\
\hline TOTAL & 13 & $0,05 \%$ \\
\hline
\end{tabular}

Fonte: IBGE, 2010.

A pesquisa foi realizada entre os anos de 2014 e 2016 com a devida autorização da Superintendência Regional de Educação (SER) e contou com a anuência dos professores da EEDRF, que se mostraram favoráveis à investigação, e nenhuma objeção foi feita. À época da pesquisa a EEDRF era a única que oferecia o Ensino Médio na região distrital e contava com 430 alunos matriculados e regularmente frequentes nos três turnos. Por meio de um levantamento realizado em maio de 2015, todos os 320 alunos dos últimos anos do Ensino Fundamental (EF) e do Ensino Médio (EM)² foram indagados sobre seu interesse em participar da pesquisa e sobre sua opção religiosa. O resultado foi o seguinte:

2 Apenas para fins de esclarecimento, os últimos anos do EF correspondem ao sexto, sétimo, oitavo e nono anos; o EM é composto pelo primeiro, segundo e terceiro anos. 
Imagens 2 e 3: Fachada e Pátio da Escola Estadual de Ribeirão da Folha.


Fonte: Acervo da pesquisa.

Dos 25 alunos que se declararam da IEAD, 6 disseram não ter interesse em fazer parte da pesquisa porque se encontravam distantes da igreja e outros 6 não obtiveram o consentimento de seus pais, restando 13 alunos: Marilene, Edna, Rosiane, Kenia, Keuani, Lucimara, Geovana, Mariane, Jucilene, Calebe, Silvane, Israel e Dilma, cujos nomes fictícios foram escolhidos por eles.

Quadro 2: Pertencimento religioso dos alunos da EEDRF.

\begin{tabular}{|l|l|}
\hline IGREJAS & ALUNOS \\
\hline Igreja Católica & 267 \\
\hline Igreja Assembleia de Deus & 25 \\
\hline Igreja Deus é amor & 16 \\
\hline Igreja Casa de Oração & 10 \\
\hline Igreja Jesus é o Caminho & 2 \\
\hline
\end{tabular}

Fonte: Elaborado pelos autores.

Essas e outras provocações modelam este artigo, que tem como objetivo central compreender quem são esses jovens alunos, como pensam e reagem às alteridades que carregam e visibilizam no ambiente escolar, por meio, sobretudo, de suas performances corporais nas aulas de Educação Física. 


\section{Os meninos, por eles e por nós: a observação e os cadernos de campo}

O caderno de campo, no processo da observação participante, é um instrumento consagrado da etnografia, associado a outros procedimentos, tais como: histórias de vida, relatos orais e audiovisuais, fotografias, croquis, desenhos, narrativas, censos e outros, como já nos ensinou Malinowski (1984). Oliveira (2006), em um artigo já canônico sobre a investigação em Ciências Sociais, da qual a observação é uma das principais técnicas, numa reflexão aparentemente simples, mas refinada e complexa, aborda a pesquisa qualitativa em que três atos epistemológicos se fazem necessários: o olhar, o ouvir e o escrever. Não como atos lineares e sucessivos, mas como atitudes de pesquisa que se entrecruzam e dialogam ao mesmo tempo. No lastro desta conversação é que entendemos a etnografia como uma dimensão que, historicamente, institui a matriz disciplinar antropológica. Ou seja, e nos termos assertivos da antropóloga Mariza Peirano (2019:173):

No fazer etnográfico, a teoria está, de maneira óbvia, em ação, emaranhada nas evidências empíricas. Mais: a união de etnografia e teoria não se manifesta apenas no exercício monográfico. Ela está presente no dia a dia acadêmico, em sala de aula, nas trocas entre professor e aluno, nos debates com colegas e pares, e especialmente na transformação de eventos de que participamos ou que observamos em "fatos etnográficos", como diria Evans-Pritchard. Desta perspectiva, a etnografia é uma forma de ver e ouvir, uma maneira de interpretar, uma perspectiva analítica, a própria teoria em ação.

Em nossa etnografia, o caderno de campo, para além de seu uso costumeiro por antropólogos, foi proposto aos alunos com quem interagimos como recurso para que fizessem registros textuais de seus modos de pensar acerca de variados temas e tempos de suas histórias e memórias. Em outros termos, duas lógicas foram subvertidas na pesquisa: o caderno do pesquisador passou a ser, também, um recurso de uso dos alunos que, por sua vez, foram instados a se apropriar de um objeto consagrado na cultura escolar para atribuir-lhe outros papéis e significados, num movimento de "despedagogização" de seu pensamento e escrita.

Sabemos quão tensa é a relação de estranhamento a ser feita pelo antropólogo a fim de alcançar mais compreensão das alteridades, num exercício permanente de relativização. Ou de deslocar-se da superfície das culturas e imergir nas suas profundezas para alcançar com mais densidade os significados por elas enfeixados segundo Geertz (1978) em seu clássico texto sobre a briga de galos em Bali. Portanto nos ativemos às proposições geertzianas de que a cultura é pública e o comportamento humano, por onde os fios dessas culturas são tecidos, é ação simbólica, pois têm significados e cabe aos pesquisadores alcançar e interpretar o mais profunda e densamente tais sentidos.

Esse movimento constituiu-se num outro desafio para os pesquisadores, os quais, também com a leitura de Geertz, defrontam-se na transcrição e interpretação daquelas alteridades ou do "outro”, com o debate sobre a natureza e a autoridade do texto antropológico na escrita etnográfica, ou, numa feliz expressão: deslocar-se “do campo ao texto”, com a pretensão de falar do "outro”. Na apresentação do 
livro de Clifford (2002), A experiência etnográfica: antropologia e literatura no século XX, Gonçalves (2002:18,19) contextualiza-o:

O dilema atual está associado à desintegração e à redistribuição do poder colonial nas décadas posteriores a 1950 e às repercussões das teorias culturais radicais dos anos 60 e 70 . Após a reversão do olhar europeu em decorrência do movimento da "negritude", após a crise de conscience da Antropologia em relação a seu status liberal no contexto da ordem imperialista, e agora que o Ocidente não pode mais se apresentar como o único provedor de conhecimento antropológico sobre o outro, tomou-se necessário imaginar um mundo de etnografia generalizada.

Problematizando a autoridade do texto etnográfico, Clifford (2002) propõe quatro modos de autoridade: o experiencial, o interpretativo, o dialógico e o polifônico. E entende que os dois últimos tipos podem resolver, pelo menos em parte, o dilema da escrita e da sua autoridade. O dialógico, por permear a etnografia como resultado de um texto cuja produção é parte de uma negociação que envolve múltiplas vozes, conscientes e politicamente significativas; e a polifônica, por romper com os textos de uma única voz. O autor propõe, então, que o conhecimento etnográfico resulte da colaboração explícita e extensa dos informantes no percurso da etnografia. É nessa lógica de um pensar e escrever complexos sobre representações culturais entre alteridades presentes na realidade escolar que nos esforçamos para compreender e textualizar como pensa, age e se representa um grupo de alunas e alunos regulamente matriculados e frequentes dos últimos anos do EF e do EM da Escola Estadual Ribeirão da Folha (EERDF).

Nesse movimento dialético e sempre tensionado do campo ao texto, uma escolha assumida por nós foi a de que a escrita da etnografia, como apropriadamente explica Ricardo Vieira (2003), é uma terceira versão resultante do encontro entre culturas e alteridades datadas e espacializadas no tempo da realização da pesquisa empírica em diálogo com os aportes teóricos ${ }^{3}$. Desse modo, temos a consciência de que o texto aqui apresentado é uma versão interpretativa na qual buscamos estabelecer uma correspondência entre sentido da ação e significado das representações na qual se centra o problema hermenêutico da interpretação e significação. Nessa linha de encontro e compartilhamento de intersubjetividades, Vieira (2003) argumenta que o texto etnográfico resulta de três sujeitos, e não de dois. Explicando: o texto etnográfico não é apenas dos pesquisadores, ele expressa um pensamento e uma escrita que foram, também, dos "nativos" e do que resultou dessa fusão de horizontes. Como bem expressa o antropólogo português:

Entrevistado e entrevistador alcançam dimensões do pensamento que não são passíveis de equacionar numa simples aritmética tipo $1 \mathrm{e} 1=2$. O resultado é possivelmente melhor traduzido por um 3, símbolo da criação, pois contém uma descoberta e racionalização que resulta da existência da interacção entre pelo menos dois sujeitos (Vieira, 2003:86).

3 No caso desta etnografia, a escrita do texto é coletiva. Com base na dissertação produzida e orientada por duas das pesquisadoras, o terceiro pesquisador participou desde o início da pesquisa, contribuindo, particularmente, mas não só, com os estudos sobre etnografia e corpo. 
Cada um dos estudantes será apresentado por ele mesmo, numa transcrição literal de suas anotações em seu caderno de campo e nos registros de nossas observações. Ao ler os cadernos, o entrecruzamento de memórias, histórias e imagens ficou bastante explícito, rompendo com as obrigações e disciplinamentos com que recorrentemente se usa o caderno nas rotinas escolares. Os meninos e meninas da pesquisa são apresentados, também, individualmente e em duplas, em consonância com dados de nossa observação sobre as interações entre eles e os modos como recorrentemente chegavam e encontravam seu lugar na escola ou na quadra. O grupo, como os demais alunos da escola, é parte da população local, cujo nível socioeconômico é baixo. A maioria deles era de filhos de trabalhadores rurais e beneficiários dos programas sociais do governo federal à época ${ }^{4}$.

Quadro 3: Alunos pesquisados e horário das aulas de Educação Física.

\begin{tabular}{|c|c|c|c|}
\hline ALUNOS & IDADE & SÉRIE & DIAS E HORÁRIOS \\
\hline Jucilene & Jucilene 17 & 3 으 & Terça - feira, 3o e 4ㅇ horários. \\
\hline $\begin{array}{l}\text { Edna Marilene, Israel e } \\
\text { Dilma }\end{array}$ & $\begin{array}{l}\text { Edna } 17 \\
\text { Marilene } 16 \\
\text { Israel } 18 \\
\text { Dilma } 15\end{array}$ & 10 anol & Sexta - feira, 2 e 3으 horários. \\
\hline Rosiane & Rosiane 16 & 1 음 $\mathrm{L}$ & Sexta - feira, 4ㅇ e 5으 horários. \\
\hline Calebe e Silvane & $\begin{array}{l}\text { Calebe } 14 \\
\text { Silvane } 14\end{array}$ & 9 ano $T$ & $\begin{array}{l}\text { Terça - feira, 3ํ horário. } \\
\text { Sexta - feira, 1으 horário. }\end{array}$ \\
\hline Kenia & Kenia 14 & 90 ano $\mathrm{M}$ & Quarta - feira, 2ㅇ e 3ㅇ horários. \\
\hline Keuani e Lucimara & $\begin{array}{l}\text { Keuane } 13 \\
\text { Lucimara } 14\end{array}$ & 8 ano $\mathrm{M}$ & Quarta - feira, 4ㅇ e 5으 horários. \\
\hline Geovana e Mariane & $\begin{array}{l}\text { Geovana } 12 \\
\text { Mariane } 12\end{array}$ & 70 ano $\mathrm{M}$ & Terça - feira, 2ㅇ e 3으 horários. \\
\hline
\end{tabular}

Fonte: Elaborado pelos autores. No ano de 2015 cada turma da EEDRF era identificada com uma letra do alfabeto.

Marilene estava matriculada no primeiro ano do EM do turno matutino, tinha 16 anos e frequentava a IEAD desde os 14. Nasceu no distrito de Ribeirão da Folha e vivia nas proximidades da comunidade da Serra. Nunca morou em outro lugar e revelou que não era seu desejo sair, pois gostava muito do lugar onde vivia.

Sou uma garota baixa, meio gordinha, cabelos pretos, olhos castanhos e pele branca. Gosto muito de viajar. Sempre eu faço uma viagem nada muito longe só para as cidades vizinhas e o mais são para as caravanas com o pessoal da minha igreja. Vamos para shows, batizados, inauguração, encontros de jovens e assim vamos alegres. Amigos tenho um monte, como os colegas de minha igreja onde eu congrego. Geralmente meus deveres de casa faço sozinha. Mas os trabalhos de sala de aula sempre sento com alguém, mais é com Edna. Sempre nos finais de semana eu faço algo. No sábado

4 Governos de Luiz Inácio Lula da Silva (2003-2011) e Dilma Rousseff (2012-2016), ambos do Partido dos Trabalhadores (PT). 
de manhã ajudo minha mãe arrumar a casa, depois faço meus deveres de casa e à noite vou para a igreja e no domingo vou para um campo de futebol com meus amigos jogar bola ou então faço um passeio para outro lugar. Gosto muito de assistir televisão como novelas e outros programas, pois não tenho internet (Marilene).

Edna estava com 17 anos e frequentava a mesma IEAD "desde criança”. Não trabalhava fora, ajudava nos serviços domésticos na casa de sua avó, onde morava. Dedicava seu tempo aos estudos e depositava seus sonhos no ingresso no Ensino Superior para conseguir um bom emprego, "para meu sustento e também para ajudar meus pais", e relatou que nunca viajou para lugar algum.

Sou morena, alta e magra. Tenho vários amigos... Geralmente faço os deveres de casa sozinha. Eu faço os trabalhos na maioria das vezes com minha amiga Marilene. Em finais de semana eu vou à Igreja e saio com os amigos. Uso internet sim e assisto televisão, eu acesso todo dia, faço mais é mexer no Facebook (Edna).

Rosiane cursava o primeiro ano do EM. Ela é irmã de Mariane e Lucimara, que apresentaremos adiante. Mostrava-se uma menina calada, tímida e não gostava de participar de atividade prática. Ela comentou que somente foi brincar depois que estava mais crescida e só se lembrava de que, quando criança, gostava de observar aqueles que estavam brincando. Acrescentou que teve "uma infância muito boa, apesar de que era difícil pra ir pra escola, era muito longe e passávamos por muitos perigos e éramos muito pequenos, mas era divertido". Sempre morou na comunidade do Cedro, trabalhando em casa ajudando a sua mãe nos serviços domésticos. Viajou para vários lugares, cidades próximas em caravanas.

Eu defino meu corpo normal, sou um pouco baixa, tenho 16 anos, olhos castanhos, morena clara, cabelo preto longo e cacheado, sou educada, não gosto de magoar ninguém, não gosto de brigas, mas sou estressada, respeito as pessoas, principalmente quem é mais velho que eu. Nos fins de semana eu, minha família e parentes reunimos, assamos frango ou fazemos churrasco e também vamos a igreja e ensaios. Eu assisto televisão, mas sendo ela sem antena. Eu tenho acesso à internet, mas não é sempre, o que eu faço é pesquisa e tenho Facebook, mas isso é só de vez em quando e o que faço mais mesmo é conversar no Facebook. A minha vida é ótima graças a Deus não me falta nada. Eu pertenço à Igreja Assembleia de Deus. Na minha casa somos sete pessoas e todos são da mesma religião (Rosiane).

Ao falar de si mesma, Rosiane não se esquecia de dizer que era educada: pelo que depreendemos, significava harmonia no relacionamento familiar, solidariedade e gentileza para com os outros sem magoá-los. Ela destacava que a sua vida sempre fora muito boa. Em sua casa assistia apenas ao DVD, não tinha antena para assistir aos canais abertos e aos fechados de televisão. Ressaltava, ainda, que seus pais eram da IEAD há muitos anos e que ela já nasceu em "berço evangélico”. Acrescentou que: "se alguém precisar, minha família oferece ajuda, e os outros também nos oferecem ajuda se precisarmos" (Rosiane). 
Kênia estava matriculada no nono ano do EF, tinha 15 anos e foi a única entre as alunas da IEAD de sua sala que aceitou participar da pesquisa. Ela é negra, usa cabelo preso com arcos e algumas presilhas, veste camisa social, vestidos e saias na altura dos joelhos. Nasceu na cidade de Minas Novas e sempre morou na comunidade do Estreito. Em sua casa são seis pessoas e todas pertencem à IEAD. Seus pais são da Igreja há 20 anos.

Sou magra, morena, cabelo preto e olhos pretos. Eu trabalho em minha casa, lavo roupa, arrumo casa, faço comida, varro terreiro, lavo vasilhas, arrumo cozinha, etc. Já viajei para Capelinha, Angelândia, Minas Novas, Veredinha e algumas comunidades próximas. Nos finais de semana, na sexta-feira converso bastante com os meus amigos no ônibus e vou para casa descansar da escola e faço algumas tarefas de casa. No sábado vou arrumar a casa e depois fazer os deveres da escola e quando sobra tempo vou à casa de minhas amigas passear. No domingo vou à igreja e depois que termina o culto vou conversar com meus amigos(as) e depois vou na casa de minha vó, em seguida vou para casa descansar para a escola na segunda-feira em diante. Gosto de tratar as pessoas bem, de respeitar as pessoas e ser respeitada também. Eu gosto muito de passear. Não assisto televisão e não tenho internet porque a televisão tem muita coisa boa, porém tem muita coisa ruim que é contra a vontade de Deus. Eu sou da Assembleia de Deus. Sou muito grata a Deus pelo que ele fez e faz na minha vida e na vida da minha família e, enfim, na vida de todos. Eu te amo Jesus Cristo. Minha infância foi muito boa e continua sendo boa, porque eu tenho muitos amigos e colegas, eu sou uma grande estudante, gosto muito de minha família (Kênia).

Keuani e Lucimara eram alunas do oitavo ano do EF. Keuani tinha 13 e Lucimara 14 anos de idade.

Meu nome é Keuani, tenho 13 anos e nasci na cidade de Minas Novas. Sempre morei na comunidade do Estreito. Eu pertenço à Assembleia de Deus. Eu trabalho em casa mesmo. Eu tenho muitos amigos. Faço meus trabalhos e atividades com minha prima. Eu sou morena, cabelos pretos, olhos pretos e sou cristã. No domingo eu vou à igreja e na casa de minha vó. Não uso internet nem assisto televisão. Fui a um show gospel, eu curti muito, pena que foi pouco (Keuani).

Lucimara mostrava-se uma aluna discreta, e assim como sua irmã Rosiane não assistia à televisão. Apesar de Rosiane algumas vezes acessar a internet, Lucimara admitia que não utilizava redes sociais. Ela parecia sempre séria, dificilmente a vimos sorrindo.

Em todas as aulas chegava até a quadra com um moletom de capuz e saia na altura do joelho. Passava grande parte do horário da aula quieta num canto da quadra com as mãos no bolso da blusa. Ela relatou que fazia os trabalhos e deveres de casa sozinha, aparentava calma e concentração. Todos os dias ela chegava, encostava em um canto da quadra com as colegas, lia um livro ou pegava uma corda e começava a bater para as suas amigas pularem. Uma aluna convidou-a para pular e ela, com um sorriso tímido, balançou a cabeça dizendo que não.

Nasci na comunidade de Pedra Preta, mas sempre morei na comunidade do Cedro. Eu pertenço à Igreja Assembleia de Deus. Meu pai é evangélico há 16 anos e minha mãe há 18 anos. Eu tenho 
1,54 m, peso 58 quilos, sou morena, tenho cabelos cacheados. Trabalho em casa mesmo lavando louças, roupas, casa, etc. Tenho muitos amigos, mas a metade deles são evangélicos, da minha igreja e de outras também. Faço meus deveres e trabalhos de casa sozinha. Eu tenho uma vida muito legal. Eu não pratico nenhum evento esportivo na minha igreja e como não pratico na minha igreja também não pratico na escola (Lucimara).

Geovana e Mariane estudaram os anos iniciais do EF na mesma escola de sua comunidade, participaram de praticamente as mesmas atividades físicas e os gestos eram bem parecidos. As duas tinham 12 anos de idade e cursavam a sétima série.

Eu sou da Assembleia de Deus. Na minha casa nós somos sete pessoas e todos são da mesma religião. Eu uso saia, não corto cabelo, não uso esmalte e nem batom. Eu tenho muitos amigos na minha igreja e em outras igrejas na escola e na comunidade onde moro. Nos finais de semana eu vou na minha igreja e na casa de meus amigos. Não uso internet e a minha televisão é sem antena (Mariane).

Morei na comunidade de Pedra Preta, mas agora moro na comunidade do Cedro. Eu pertenço à Assembleia de Deus. Na minha casa somos seis pessoas e somos todos da mesma religião. Já faz cinco anos que minha família pertence a essa religião. Eu uso saia composta, não uso blusa sem manga, não posso usar maquiagem, batom e nem brinco. Eu tenho bastantes amigos, mas a maioria é da Assembleia de Deus, tenho alguns que são católicos. Eu faço os deveres e trabalhos sozinha. Nos fins de semana eu vou à igreja. Eu assisto só DVD evangélico e não acesso internet (Geovana).

Jucilene tinha 17 anos e estava no terceiro ano, nasceu na cidade de Minas Novas, morou algum tempo em Capelinha e veio para a EEDRF transferida de uma escola daquela cidade. Conhecia Belo Horizonte. Geralmente ela ficava afastada, não se enturmava e não participava dos esportes coletivos. Todavia foi a única aluna, entre todos os alunos das diferentes denominações religiosas, que participou dos ensaios e da tradicional dança realizada na escola em comemoração aos santos juninos. Ela não revelou se teve o consentimento de seus pais, mas participou da festa. Observamos pela sua fala que ela se sente presa a costumes que não gostaria de seguir. Ela acrescentou ainda que "as regras da igreja são exigências além do preciso”.

Sou magra, tenho 1,57 metros. Minha pele é cor clara; cabelo castanho claro e crespo. Sou uma jovem bonita e legal. Tenho apenas dois amigos, primeiramente Deus e o outro se chama Luiz Fernando. Desde minha infância eu fui uma criança afastada das outras, eu brincava de bonecas, mas sozinha. Nos finais de semana eu gosto de ficar em casa mesmo, e garrada com meu celular. Gosto de ver TV também, mas internet não tenho em casa. Quando acesso internet, eu gosto de falar no Facebook e no WhatsApp com pessoas fora do Brasil (Jucilene).

Calebe e Silvane cursavam o nono ano do EF. Os dois tinham 14 anos e moravam no distrito de Ribeirão da Folha. Silvane usava saia com tecidos mais leves, algumas vezes short jeans acima do joelho. 
Ela afirmava que o seu relacionamento com os colegas de sala era muito difícil, "eles não gostam de mim e de meu amigo Calebe”. Mas não se importava, pois tinha outros amigos:

Eu tenho muitos amigos, tenho amigos na igreja que simplesmente vejo como irmãos, apesar de sermos todos irmãos em Cristo. Eu uso internet e assisto televisão, não vejo nada demais nisso. O pastor diz que é preciso saber usar. Eu gosto mais de ouvir músicas evangélicas e acessar meu Facebook. Lá posso conversar com outras pessoas evangélicas e também com meus parentes e irmãos. Eu congrego na Assembleia de Deus. Em minha casa ao todo somos sete pessoas e nem todos são evangélicos. Eu e um amigo ensinamos as crianças sobre Jesus e fazemos brincadeiras com elas (Silvane).

Calebe assim se apresentou:

Sou desempregado, às vezes ajudo a minha mãe a arrumar a casa. De vez em quando eu viajo e passeio com meus amigos e família. Eu sou uma pessoa que em certas ocasiões eu gosto de ficar sozinho, tipo fazer as tarefas de escola, mas meus amigos não compreendem isso. Minha infância foi divertida, eu não vou falar mais porque eu não lembro. Assisto TV, isso é o meu passatempo, é com a internet que eu me divirto e converso com meus amigos e a TV me ajuda a esquecer de várias coisas. Ah! Nos finais de semana eu passeio com meus amigos e vou à igreja. É isso que eu faço o ano todo (Calebe).

Israel e Dilma eram alunos do $1^{\circ}$ ano do EM, turno da manhã. Durante as observações as suas vozes não foram ouvidas. Israel participava de todas as atividades propostas nas aulas. Dilma, por sua vez, não participava e ficava encostada no alambrado da quadra sem se movimentar muito. Israel é alto, usava sempre calça e camisa social. Na maioria das vezes, o vimos usando chinelos. À época da pesquisa de campo tinha 18 anos, nasceu na cidade de Minas Novas e sempre morou na comunidade do Estreito.

Sou da Igreja Assembleia de Deus, tenho 18 anos. A minha infância foi muito boa, eu adorava muitas brincadeiras como carrinho, bola, peteca e esconde-esconde. Na minha família somos cinco pessoas, mas não somos da mesma religião. Trabalho sempre nas férias escolares, nunca viajo para lugar longe. Tenho um corpo lindo e saudável. Eu tenho muitos amigos, os deveres de casa eu faço sozinho. O meu relacionamento com os colegas é de respeito e compreensão. Nos finais de semana vou à igreja ou na casa de meu vizinho. Eu não assisto televisão e não mexo com internet. Não usamos a internet porque na internet tem muitas coisas boas e ruins. Para mexer com as boas temos que passar pelas ruins e a televisão é a mesma coisa (Israel).

Dilma, com 15 anos, nasceu na cidade de Minas Novas e também morava na comunidade do Estreito. A respeito de sua infância, ela revelou ter brincado e se divertido muito com as suas primas. "Eu gostava de brincar de boneca, peteca, cozinha e outros. Eu gostava muito de brincar".

Eu sou magra, alta, cabelos anelados, cor parda. Eu sou comportada. Tenho 1,63 metros e peso 46 quilos. Eu trabalho, arrumo casa, lavo roupas, varro terreiro, lavo vasilhas, e outros. Eu tenho muitos amigos. Eu faço meus deveres sozinha. Nas salas de aulas com outras três meninas. Nos finais 
de semana faço meus deveres, vou passear na casa de minhas amigas, vou na casa do namorado da minha irmã e aos domingos vou à igreja e divertimos muito. Eu sou da Assembleia de Deus. Na minha casa somos oito pessoas. Somos eu, meus irmãos, pai e mãe. Meu pai e minha mãe são da Assembleia, meus dois irmãos mais velhos são católicos. A minha mãe faz quatros anos que ela é da Assembleia e meu pai faz um ano (Dilma).

\section{Os alunos e sua orientação religiosa: narrativas sobre tal pertencimento e os corpos}

Tanto pelos registros no caderno de campo dos alunos quanto pelas manifestações nas entrevistas realizadas, evidenciou-se que a orientação religiosa na IEAD não foi uma escolha, mas está enraizada na tradição e na imposição familiar de cada um deles. Bem como foram explicitamente destacadas a disciplina e as sanções como elementos que levam à modelagem de comportamentos nas aulas de Educação Física e nos cultos promovidos pela referida igreja. Edna, por exemplo, contou: "disciplina é ficar no último banco quando erramos. Quando fazemos algo errado eles colocam a gente no último banco e quem é batizado fica sem tomar a santa ceia”.

Marilene é bastante enfática em relação à disciplina e às sanções para quem não a segue rigorosamente. E termina por nos mostrar como a igreja classifica e define a estadia espacial dos fiéis no templo:

Disciplina na igreja é tipo como se você ficasse de castigo. Na igreja existe um espaço para cada grupo de membros. Jovens no banco de jovens, irmãos com irmãos, criança com criança, irmãs com irmãs e os bancos de trás para as visitas que vão na igreja que não são crentes.

Tal classificação baseia-se em supostas relações de afinidade e de parentesco estritamente vinculadas aos laços familiares e à faixa etária e na importância atribuída a quem é fiel. Os lugares da frente, com o significado que carrega em termos de hierarquia e distinção, são ocupados pelos crentes. Os bancos lá de trás, como lugares menos importantes na classificação feita, podem ser ocupados por aqueles que estão presentes na igreja, mas não são fiéis. Em outros termos, são pessoas convidadas a entrar no templo, mas são menos importantes pelo seu não pertencimento à IEAD.

Todavia, mesmo os fiéis, aqueles que foram iniciados na igreja por meio do ritual do batismo nas águas, "descer às águas" para emergir purificado, são alvo de sanções e punições se cometerem algo de errado; e um dos atos para dar visibilidade à indisciplina é eles se sentarem, também, nos bancos de trás. Marilene relatou:

A partir do momento que eu pratico algo errado, contra as regras, se eu for batizado, ou seja, se eu descer às águas, eu sou colocada no banco de trás ficando lá um certo tempo sem participar da ceia do senhor, sem beber o cálice e comer o pão. Isso é chamado indisciplina, você não estar em comunhão com Cristo. Existe o capítulo 11 - versículo 27 a 34 de Coríntios que fala um pouco sobre isso, que diz assim: portanto, qualquer que comer este pão ou beber o cálice do Senhor indignamente será culpado do corpo e do sangue do Senhor. 
O batismo para os fiéis da IEAD é o "mergulho nas águas", um mergulho profundo que inunda a pessoa por inteiro e que se conecta ao estado de purificação e sua quebra com atos de indisciplina. Como alerta Dilma:

A disciplina em nossa igreja é para pessoas que desobedecem às regras da igreja, como cortar cabelo, vestir inadequadamente, falar mal dos outros, ouvir músicas de pessoas católicas. A disciplina é só para as pessoas batizadas que cometem erros. O batismo evangélico é só para pessoas acima dos 14 anos. O batismo é morrer para o mundo e nascer para Deus. No batismo evangélico não pode deixar nem um fio de cabelo fora da água dos rios (Dilma).

Marilene foi mais adiante ainda em sua fala. Ela nos explica não apenas sobre as punições para quem "quebra as regras"; a isso se soma um elemento fundante das religiões, que é o ato fortemente simbólico do comer, da alimentação do pão e do vinho. Ocupar os bancos lá dos "fundos" é reforçado pela interdição ao alimento que purifica o corpo e a alma. Desse modo, na classificação demarcada espacialmente, mostra-se e se expressa a indisciplina e a impureza dos fiéis, que podem "ficar fracos, doentes" e sonolentos. Portanto um dado de alteridade interna no grupo fica claramente sublinhado para o ambiente externo. E remete aos que ainda não fazem parte do corpo de crentes, como uma repreensão antecipada de natureza pedagógica. O pertencimento à IEAD passa pela obediência aos princípios doutrinários daquela denominação religiosa. E a ocupação dos assentos na igreja carrega essa marca densamente simbólica.

No relato de Rosiane, encontramos um ponto de vista similar ao de Marilene, ambas compartilham da compreensão do que significa "quebrar as regras". O disciplinamento é uma prescrição que se estende para outro elemento muito expressivo da IEAD, qual seja, cantar durante os cultos. Para isso, são formados os corais, que encerram uma marca distintiva nos momentos de louvação. Se um escolhido para cantar comete algum erro, ele é excluído e não é fácil retornar. O comportamento daquele que entoava cantos e cometeu um "erro" passa necessariamente por um tempo não definido em que ele será observado atentamente e julgado no cumprimento da punição.

Disciplina na minha igreja é quando um irmão faz um erro grave, ele fica sem participar da ceia, que é o símbolo da carne e do sangue do Senhor. Se for alguém que canta em conjunto ficará sem cantar e não terá a oportunidade. Mas isso tem um tempo determinado, se vai ser de seis meses, um ano ou até mais. Se completar o tempo e não estiver saído do erro ele não sai da disciplina (Rosiane).

A vida privada dos fiéis não é poupada do julgamento moral da igreja e das possíveis punições. O aluno Israel vai direto ao ponto: "disciplina é se os casais brigarem, as mulheres cortarem os cabelos, se o seu modo de vestir não estiver correto como a Bíblia manda, isso é indisciplina”. Assim, a igreja tenta impor controle e disciplina para os fiéis que já são batizados com base nas regras, normas e condutas e também restrições relativas ao comportamento e atitude. Sairão da condição de disciplinamento (punição) aqueles que não cometerem mais o erro. Não podemos deixar de anotar que a escola tem regras parcialmente similares. Carteiras dos fundos são ocupadas por alunos considerados indis- 
ciplinados. A proibição de ir ao recreio e não desfrutar da aula de Educação Física é regra observável nas rotinas escolares.

Nossos alunos na pesquisa certamente não ocupariam os bancos do fundo da sala de aula, pelo comportamento comedido que reconhecem ser devido à orientação religiosa. Parecem conversar sempre em tom de voz muito baixo, são quietos, calmos, não respondem mal aos colegas ou aos professores. Também condenam tumultos ou alvoroços, assim como pouco perguntam ou questionam. São contidos em suas palavras, como o são com seus corpos. "Nós evangélicos temos que pensar muito antes de falar algo", comentou Edna. Sua colega Rosiane emendou: "não podemos falar palavrões nem falar dos outros nem responder os outros com falta de educação. Temos que dar exemplo".

Essas alteridades se opõem a comportamentos juvenis nas escolas e fora dela, já largamente tematizados e discutidos em pesquisas acadêmicas e de mercado que retratam adolescentes e jovens estudantes com atuação ruidosa e transgressora, confrontando alteridades (étnico-raciais, de gênero, geração, econômicas, etc.) e autoridades (familiar, docente), tendo, muitas delas, como eixo a discussão das identidades.

No âmbito das pesquisas que tematizam adolescência e juventude, podemos delimitar duas perspectivas distintas, mas complementares: aquelas cujo foco são os problemas sociais que atingem a população jovem. Destacam-se nessa via estudos sobre violência, criminalidade, drogas, gravidez na adolescência, entre outros temas que interferem diretamente na condição juvenil brasileira contemporânea e na educação. Nessa direção caminham os estudos desenvolvidos por Novaes et al. (2016), entre outros pesquisadores brasileiros. E outra perspectiva busca pensar o jovem e a juventude em sua positividade, destacando, de um lado, a cultura como espaço de sociabilidade, inserção social e política juvenil. Nesse caminho, as culturas e grupos de jovens são focados como espaço privilegiado de expressão e construção identitárias, bem como territórios de construção de projetos de vida e futuro. E, de outro, pensar os jovens como sujeitos sociais e políticos, agentes na sociedade. Importante, nessa direção, são os estudos e pesquisas conduzidas por Sposito, Souza e Silva (2018), Magnani e Souza (2007), Maia (2010), Dauster e Feixa (2014), Tosta e Rocha (2011), Pereira (2018), Tosta e Diniz (2020), dentre outros.

Importa notar, porém, que, no rol dessas e outras produções acadêmicas sobre juventude, vários autores indicam que a variável "religião" tem sido pouco considerada na compreensão do perfil dos jovens na cidade. E sobre jovens no campo, recorte do presente artigo, é praticamente inexistente. Mas, paradoxalmente, censos revelam intensa influência do campo religioso na constituição da identidade desses sujeitos.

Esses corpos são vistos e representados pelos nossos alunos na pesquisa, na medida de nossa observação e interpretação. Alguns relatos e retratos são modelares para mostrar esses alunos declaradamente evangélicos, sempre, como dizem eles, tendo os preceitos doutrinários em vista. Nesse sentido, podemos perceber que no corpo das meninas, mais do que no dos meninos, as marcas da cultura religiosa se inscrevem de maneira mais acentuada, por meio de uma estética, comportamentos e gestos representados como adequados para os membros da IEAD. Tais símbolos comunicam ideais de ser "crente" e colaboram para o entendimento e percepção dos estudantes acerca de si mesmos, que têm 
como efeito a ideia de que o corpo revela ou pode comprovar em sua materialidade as principais características de sua subjetividade ante a moralização do corpo apregoada pela IEAD.

Não obstante, dita incorporação (Bourdieu, 1988), representada por meio de roupas (detidamente o uso de saia longa para as meninas), cortes e jeitos de pentear o cabelo, o (não/pouco) uso de maquiagem e gestos geralmente associados aos fiéis dessa matriz religiosa, não acontecem de maneira uniforme e tampouco na mesma intensidade por parte destes, conforme poderemos ver. Se a IEAD é uma instituição que busca educar o corpo de seus membros, a escola também o faz a seu modo, conjuntamente com outras instâncias sociais, dentre as quais se destaca a mídia. Em outras palavras, os estudantes investigados são perpassados e influenciados por outros valores, normas, percepções e representações que orientam e enformam o corpo, que vive na experiência do encontro com as coisas e as pessoas (Le Breton, 2011).

\section{Corpos em movimento: cabelos, roupas, maquiagens e sociabilidades}

Em uma interpretação holística, oportunizando encerrar no corpo o somatório dos aspectos biológicos, socioculturais e psíquicos, este se configura como um conjunto único de interações com sua exterioridade, o que condiz com as reflexões de Le Breton (2011:7) quando manifesta:

Moldado pelo contexto social e cultural em que se insere, o corpo é o vetor semântico pelo qual
a evidência da relação com o mundo é construída: atividades perceptivas, mas também expressão
dos sentimentos, cerimônias dos ritos de interação, conjunto de gestos e mímicas, produção de
aparência, jogos sutis de sedução, técnicas do corpo, exercícios físicos, relação com a dor, com o
sofrimento, etc. Antes de qualquer coisa, a existência é corporal.

Desde essa perspectiva, compreendemos o corpo como lugar de comunicação, de diálogo, de experimentação nas relações com as coisas e com os outros, pois não se encontra alienado das experiências, vivências, afetos, motivações e biografias. Espaço e motivo de infinitas representações, o corpo é um complexo semântico que se traduz em muitos saberes e olhares, várias formas de percebê-lo e vivê-lo. Essa heteroglossia que perpassa e constitui os corpos é influenciada e marcada pelas descobertas científicas e tecnológicas, pelas ideologias e discursos religiosos, pela mídia, pelas demandas econômicas, políticas, sociais e culturais. E o lugar de destaque que ele tem ocupado nas últimas décadas em sociedades industrializadas e fundamentadas pela lógica do capital, bem como ser móvel de várias pesquisas, dá-se pelas possibilidades de sua desconstrução e modificação, principalmente a partir das tecnologias corporais que se difundem a cada dia, relacionadas à moda e à indústria da beleza, e também ao desenvolvimento técnico-científico em favor da promoção e manutenção da saúde e do bem-estar.

Você é seu corpo! - evocam as mensagens disseminadas por várias instâncias sociais, destacadamente a mídia. O corpo, então, de acordo com os padrões estéticos instituídos e reificados socialmente na atualidade, em várias sociedades ocidentais, é eleito como signo essencial de beleza e de poder, o que 
implica aos atores de diversas camadas sociais, em diferentes países, a reivindicação de trabalho contínuo, transformação e modelagem dos corpos.

Na perspectiva de Le Breton (2011), o corpo tem se convertido em alter ego para grande número de pessoas, tal qual um outro que pode ser continuamente maleável, modelável de acordo com seus desejos e expectativas, vislumbrado como se fosse um cartão de visitas de carne e osso. Reconhecido como mecanismo de valorização social, o corpo tende a ser percebido como um capital (Goldenberg, 2006) que, em razão de seu cuidado e da aparência, tem motivado várias práticas de consumo. Le Breton salienta que o corpo é indiscernível do sujeito, está sempre presente, independentemente da forma como são utilizadas sua vitalidade, força e sensorialidade. No entanto, como ele tem buscado demonstrar, o corpo tem se tornado objeto de preocupação cotidiana, lugar de destaque, distinção e hierarquização na vida social.

Vislumbradas por De Lauretis (1994) como algumas das mais profícuas tecnologias de gênero, a mídia e, especialmente, a publicidade, juntamente com distintas vozes em diversos domínios discursivos, veiculam padrões corporais e comportamentais como lícitos de serem exibidos, admirados e desejados e, portanto, considerados por muitos como meio de satisfação e realização pessoal.

É preciso considerar, ainda, o poder de agência das pessoas ante as muitas imagens constituídas que a publicidade e a mídia veiculam. De modo geral, não atendem passivamente às demandas, tampouco as interpretam e realizam-nas do mesmo jeito e na mesma proporção quando o fazem. No processo de incorporação dos aspectos culturais a esse respeito, de constituição da imagem corporal e sua exibição pública, contam as várias categorias de ordenação social, tais como gênero, classe, idade, grupo étnico, estilo de vida e, aqui, considerando os jovens pesquisados, detidamente a religião. Não dizemos, pois, do acatamento massivo das diretrizes sugeridas, pois há também possibilidades de negociação ou resistência por parte dos sujeitos.

Rosiane, Mariane e Lucimara possuíam o cabelo bem longo; Geovana, Kedma, Edna e Kênia usavam cabelo afro e curto; as colegas Marilene, Silvane, Dilma e Jucilene tinham cabelo mediano, nos ombros; os dois meninos (Calebe e Israel) exibiam cabelo curto; e Jucilene era a única aluna do grupo que tingia o cabelo. Os depoimentos mencionam as prescrições da IEAD relacionadas ao corte do cabelo, nem sempre em tom de obediência: "não é permitido cortar cabelo, mas muitas não obedecem porque isso era mais rígido antigamente, agora não é tanto" - comentou Edna. "O cabelo também não pode cortar porque ele existe no lugar do véu", disse Lucimara, remetendo à tradição religiosa que, em geral, o artefato cobre a cabeça em sinal de respeito e compostura. Para Marilene, "o cabelo mesmo eu já corto sempre. Mas eu sempre penso que o que importa mesmo é o coração, o que está dentro dele, não o que está em seu físico".

Quanto às vestimentas, as alunas, com exceção de Jucilene, Marilene e Silvane, usavam somente saias ou vestidos à altura do joelho; os meninos sempre usavam calças e em nenhum momento foram vistos usando bermuda ou camiseta sem manga, costumeiramente as roupas indicadas para aulas de Educação Física. Mais uma vez, em meio às imposições que se apoiam na tradição da igreja, o uso de calças pelas meninas é considerado uma exceção e isso mostra claramente como o corpo é generificado: 
Existem orientações sim, muitas. Como na vestimenta não pode usar roupa muito curta e nem blusa sem mangas como camisetas, e não é permitido calças para ir para a igreja, somente saia ou vestido. Eu, por exemplo, uso calça para ir para a escola, pois acho a saia meio desconfortável. O pastor diz que para estudar e trabalhar não tem problema, pode sim usar calça (Marilene).

A roupa pode ser vista como um prolongamento da pele e um elemento importante na constituição do corpo, visto que permite aos jovens investigados a expressão e o entendimento de um conjunto de ideias relacionado à sua religião e comportamentos que se pode esperar deles. Porquanto:

Para a humanidade, vestir-se é pleno de profundo significado, pois o espírito humano não apenas constrói seu próprio corpo como também cria as roupas que o vestem, ainda que na maior parte dos casos, a criação e a confecção das roupas ficam a cargo dos outros. Homens e mulheres vestem-se de acordo com os preceitos desse grande desconhecido, o Espírito do Tempo (Köhler, 1996:57-8).

A fala de Israel chamou a atenção, pela assertividade: "temos que vestir comportados porque a carne tampa os ossos e a roupa tampa a vergonha, as mulheres". Cobre a vergonha de um corpo semidespido: "existem orientações da minha igreja em relação ao modo de vestir, tem que vestir-se composta, não pode usar calça, short, blusa sem manga" - como expressou Dilma. Em relação ao uso de maquiagens, como rímel, sombras, bases e até o esmalte para as unhas, o que percebemos foram falas que guardam coerência com os preceitos da IEAD, buscando, porém, certa relativização. A exemplo de Lucimara, que relatou o seguinte:

Não podemos pintar o cabelo e as unhas, foi o que eu aprendi e eu e os meus irmãos guardamos até hoje. Muitas religiões (referindo-se às evangélicas) já permitem algumas dessas coisas, a minha religião cobra tudo isso e nós seguimos. Mas já têm evangélicos da IEAD que usam.

Edna disse: "quanto ao uso de maquiagens, não é permitido, mas ainda têm pessoas que usam". Novamente Israel foi assertivo e reforçou o valor estético de acordo com os valores apregoados pela igreja: "as mulheres não podem usar maquiagem porque é muito feio e Deus não agrada dessas coisas, senão Deus tinha feito o homem e a mulher com pintura”. Contudo, para Marilene, os crentes não seguem tão rigidamente as regras da igreja; ela mesma não usa maquiagem por uma razão estética, isto é, por causar mais espinhas no rosto, as acnes tão indesejadas pelos jovens e que marcam a puberdade.

Maquiagem antigamente não poderia nunca um crente usar. Hoje já é diferente, alguns usam, nem todos. Uns até são contra, mas outros a vaidade conspira dentro deles e acaba então sendo normal um crente usar. Eu mesmo não uso porque eu não gosto, pois tenho muita espinha no rosto e prefiro não colocar.

Essas interdições ao mundano, ao hegemonicamente usual quando falamos de adolescentes e jovens hoje, são sempre justificadas na tradição da religião à qual declararam pertencimento. Nossos 
alunos na pesquisa demonstraram adesão à IEAD, ainda que tenha sido possível notar o quanto sua alteridade causava estranhamento.

A igreja é muito legal. Eu adoro! No começo foi difícil me acostumar com todas as regras e práticas e abandonar tudo que me ligava com outros costumes. Hoje é 100\%, mas em vista do que era antes me acostumei com tudo. Na igreja você se sente tão bem que quando eu estou lá nada me abala, tem uma diferença tão grande de uma festa ou um forró que nem dá pra comparar. Em uma festa às vezes dá até morte ou briga, um acidente. Na igreja você ouve só coisas boas e acontecem com você coisas legais. Toda igreja tem certas regras e não é permitido que elas sejam quebradas. Regras são regras. Quando você decide aceitar Cristo como seu salvador, você está fazendo um pacto com ele prometendo não agir de qualquer forma (Marilene).

A lógica do pensamento mítico opera nas falas e interpõe o público e o privado, como é o caso de Silvane, que assim se expressou: "minha igreja é muito legal, Deus opera grandes maravilhas naquela igreja, lá eu me sinto a melhor pessoa do mundo, me sinto bem. Igreja é minha segunda casa”.

Possivelmente, é por meio do pensamento mágico e da evocação do sagrado que as dificuldades de aceitação dos costumes da IEAD são reelaboradas e adquirem funcionalidade em termos de manutenção e reforço do ideário que sustenta a igreja. As dificuldades foram pontuadas em vários depoimentos e no caderno de campo dos alunos, não obstante concordarem que regras não devem ser quebradas e sim respeitadas. E que, a partir do momento em que fizeram "um pacto com Cristo", não podem agir de qualquer maneira. Disseram-se "felizes na igreja”. Exceto Marilene e Jucilene, que declararam não seguir todas as regras, "mas que apesar de não segui-las, não zombam de Deus".

Se a escola, os afazeres domésticos e as atividades da própria IEAD ocupam os meninos e meninas durante a semana, nos finais de semana eles constroem espaços de lazer e sociabilidade. Isso com muitas restrições, quando os comparamos aos jovens do meio urbano, especialmente no tocante ao acesso, muitas vezes precários para os mais pobres, é fato, ao mundo digital e ao que a rede propicia. Mas, ainda assim, existem escolhas por parte deles. Dos 13 alunos entrevistados, apenas quatro - Silvane, Edna, Calebe e Marilene - assistiam à televisão por meio das emissoras abertas. Os outros usavam o suporte televisão para assistirem a DVDs. Apenas Rosiane, Calebe, Silvane, Edna, Marilene e Jucilene acessavam a internet.

Os alunos destacaram enfaticamente a possibilidade de estarem juntos nos encontros, passeios e participação em eventos organizados pela IEAD, como os cultos nas casas dos "irmãos", aniversários, shows e caravanas. São eventos muito esperados pelos fiéis, evidenciando que as atividades constituem espaços e tempos de sociabilidades, aprendizagens, criação e fortalecimento de vínculos e lazer. Alguns deles comentaram:

Nas caravanas fazemos muitas coisas legais, ouvimos sobre Deus, conhecemos pessoas novas, ouvimos cantores louvarem a Deus, louvores lindos, palestras, estudos dentro da Bíblia. O que eu mais gosto é exatamente de tudo. É verdadeiramente incrível, ainda mais o que vem de Deus (Marilene). 
"Nas caravanas eu não faço nenhuma atividade. O que eu mais gosto de fazer nas caravanas é cantar no ônibus durante a viagem e o mais é prestar atenção em tudo que for ensinado pelos pastores e no intervalo tomar um sorvete com os amigos" (Rosiane). "Nas caravanas que nossa igreja pratica nós cantamos, fazemos teatro e outros. O que eu mais gosto de fazer nas caravanas é conhecer lugares diferentes, pessoas, prestar atenção no que vai falar nos cultos" (Dilma).

Se por um lado, na cultura da IEAD, a aparência do corpo, os gestos, olhares e os comportamentos podem conduzir para a salvação ou danação eternas, e que as esferas da sexualidade e do lazer são consideradas as mais perigosas na possibilidade de se alcançar, afinal, a salvação (Mariano, 2004), por outro, não significa que o lazer não faça parte da vida dos estudantes investigados. Assim, se para alguns deles as atividades nas aulas de Educação Física podem ser vislumbradas como impróprias para quem quer alcançar a salvação eterna, daí a razão da vigilância e controle do corpo, existiam atividades de lazer próprias para os membros da IEAD e que possibilitavam diversão, conforme pudemos observar, notadamente nas caravanas. Motivação, bastante expectativa e entusiasmo para sua realização, mesmo ante os olhares atentos e reguladores dos adultos, as caravanas apresentavam para os jovens alunos um interstício entre a casa, a igreja e a escola, e eram vislumbradas como oportunidade de passear, divertir-se e rir com os irmãos da igreja.

Diferentemente da timidez e inércia que parte dos/as jovens apresentaram nas aulas de Educação Física observadas, elas e eles indicam performar sujeitos ativos nas caravanas e outros eventos da igreja. Não se trata, portanto, de corpos sem movimento, inativos. Assim sendo, seus comportamentos nas aulas de Educação Física são apenas de uma parte de suas vidas e, como esperado, não representam a totalidade de suas vivências e expressões corporais. Portanto, entendemos que, forjado na história humana, cuja narrativa se constrói na trama com outros sujeitos e coisas (Najmanovich, 2002), o corpo é miscelâneo, polissêmico e multifacetado.

\section{Perfomances corporais: alunos evangélicos nas aulas de Educação Física}

Em dias sem chuva, para a realização das aulas de Educação Física (EF), os alunos se dirigiam para a quadra localizada em outra rua e pertencente à comunidade, o que geralmente causava transtornos e disputa entre os estudantes e demais pessoas que buscavam usar o espaço. Na quadra não havia água encanada nem bebedouros. Para tanto, os alunos portavam uma garrafa pet ou térmica e, quando necessário, voltavam à escola para reabastecerem-se de água. Para amenizar os problemas de uma quadra aberta, na divisa, um grande pequizeiro, árvore típica do cerrado brasileiro que oferecia generosa sombra.

Era muito comum que os alunos pesquisados ficassem em grupos desfrutando da sombra do pequizeiro em dias de campeonatos e gincanas. Nessas ocasiões, Marilene, Rosiane, Kênia, Keuani, Lucimara, Geovane, Mariane, Calebe e Dilma sempre eram vistos juntos durante todo o tempo das atividades. Israel até gostava de jogar futsal, mas como nem sempre era escalado pelos alunos de sua sala, ele permanecia próximo de seus colegas. 
Imagens 4 a 9: Cenas das aulas de EF: ginástica, jogos, brincadeiras (jogos de dama, futebol de dedo, policinha) e atletismo (salto em distância e corrida com mudança de direção).
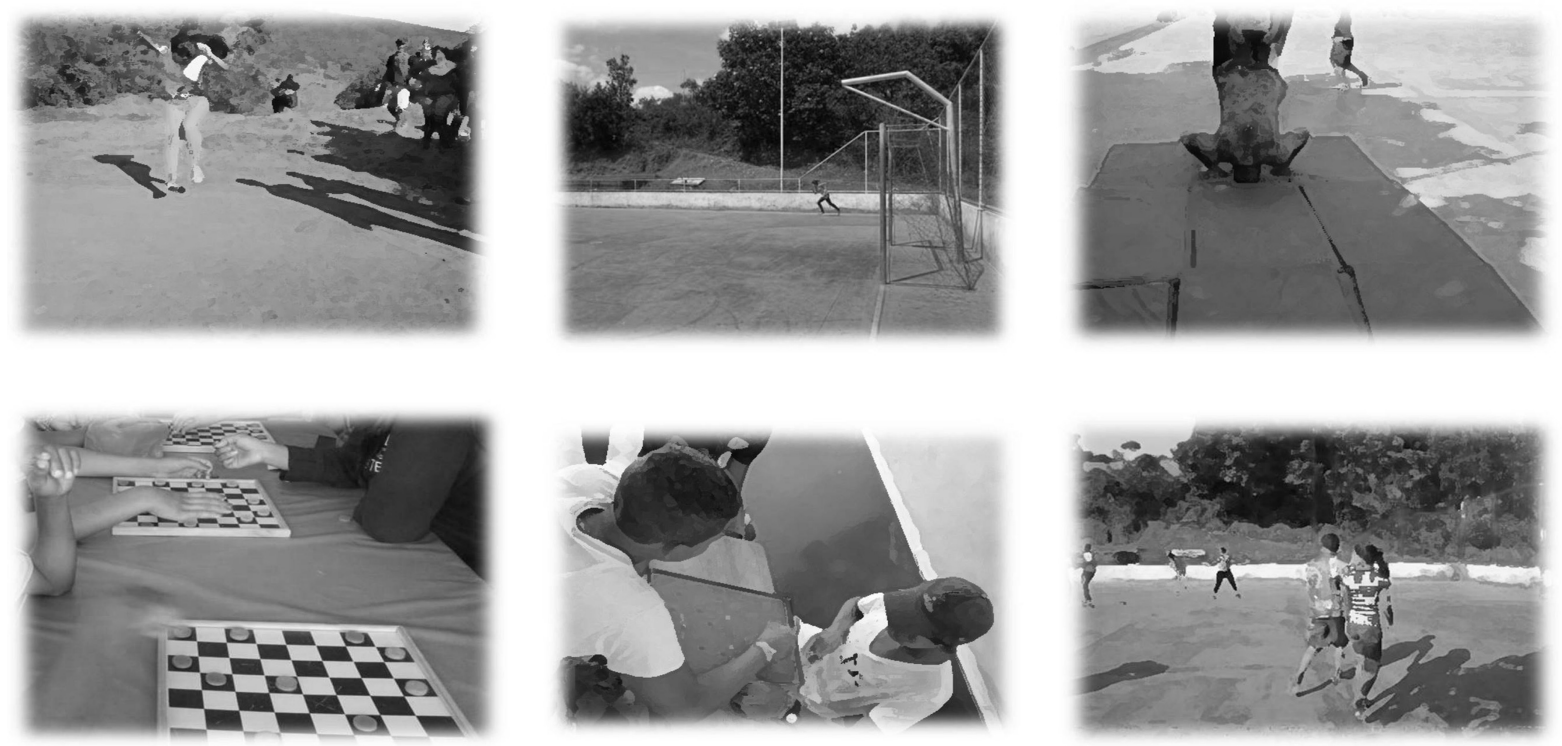

Fonte: Acervo da pesquisa.

As imagens mostram algumas das atividades observadas nas aulas de Educação Física. Em todas elas os alunos da IEAD ficaram apenas observando. Isso se explica pelas restrições impostas pela doutrina dos alunos relacionada ao corpo que, em sua maioria, impede-os de praticar determinadas atividades em que este ficaria em evidência. Destacamos as interdições, o controle, a disciplina, a orientação quanto ao modo de vestir e se comportar, entre outros.

Assim, a resistência ou recusa por parte de alguns alunos em realizar as atividades práticas indicava uma tensão recorrente entre um ethos corporal de sua religião e as demandas pela realização de atividades físicas. Nesse sentido, a fala da jovem Marilene é bastante esclarecedora: "Eu resisto em fazer a aula porque acredito nos valores pregados pela minha igreja”. Ela acrescenta: "também posso resistir aos valores pregados pela minha igreja e fazer as práticas corporais propostas nas aulas de Educação Física”.

$\mathrm{Na}$ mesma direção, era corriqueiro que Edna e Dilma, ao chegarem à quadra, pegassem uma peteca e fossem em direção ao canto da quadra, à sombra da árvore, e ali permanecessem durante todo o tempo lendo um livro ou brincando sozinhas com a peteca.

Eu participo, eu levo livro pra ler nas aulas de Educação Física, eu brinco de peteca, eu não gosto de jogar nem voleibol. Eu gostaria que as aulas fossem pelo menos um horário de brincadeiras como pique bandeira, onde todo mundo possa brincar juntos (Edna).

Eu participo das aulas de Educação Física na sala de aula. Eu não gosto de jogar futebol, voleibol, handebol porque não quero e porque a religião não gosta que jogamos [sic] futebol e outros jogos, mas joga quem quiser. Eu gosto de brincar de queimada, peteca, dama e outros. Não jogo futebol e não brinco de outras atividades (Dilma). 
A ascendência da religião sobre o comportamento de Dilma nas aulas de EF também fica evidente em sua justificativa para sua não participação nas atividades que acontecem na quadra, demonstrando que as práticas corporais são socialmente aprendidas por meio de vivência e expressão corporais cotidianas sob a influência de distintas instituições e constroem-se por meio de usos e gestos cheios de significados que condizem com o lugar de sujeito. Retomando o seminal texto de Mauss sobre as técnicas corporais que são empreendidas "em uma série de atos montados, e montados no indivíduo não simplesmente por ele mesmo, mas por toda a sua educação, por toda a sociedade da qual ele faz parte, no lugar que ele nela ocupa” (1974:218).

Influenciado por Merleau-Ponty e tomando o cerne do conceito de habitus de Mauss, Bourdieu indica que o habitus manifesta um mundo social, uma moral incorporada, como podemos depreender da fala de Edna, por exemplo. Assim, para o autor, habitus são disposições duráveis que constituem todas as experiências, gestos, ações, gostos, percepções, entre outros fatores, e que estão diretamente relacionados à pertença de um dado grupo social. Esse quadro indica que Bourdieu concebe o corpo como socialmente instituído e compreende-o como uma superfície sobre a qual a cultura impóe suas características, fazendo do corpo um lugar privilegiado de controle social e dominação.

Por meio de regras, orientações e informações que encaminham os sujeitos no devir ordinário de suas vidas, a cultura materializa-se nos corpos em atividades habituais, marcando limites e possibilidades de ação e comportamento. Essas forças ocorrem no corpo de modo inconsciente pelos sujeitos por meio da incorporação de esquemas de percepção socialmente construídos e veiculados, fazendo com que os corpos sejam ao mesmo tempo produto e reflexo das condições do entorno social. Nessa direção, os sujeitos vão se constituindo passo a passo, configurando-se por meio dos ritos, das interações com as pessoas e o contexto. Esse complexo semântico convertido em prática social é, para Butler (2003), uma questão de performatividade. A partir dos estudos dessa autora sobre a categoria gênero, entendemos que o corpo é performativo, haja vista tratar-se de uma atuação reiterada e imperiosa em função das pautas sociais que circundam e orientam as ações dos sujeitos.

Imerso na cosmovisão da IEAD, a atuação do sujeito, de acordo com o lugar que lhe foi destinado e cujas prescrições ligadas a ele devem ser seguidas, está sempre condicionada a recompensas e castigos. Diante disso, ao desenvolver uma performance corporal, não significa que esse empreendimento se dá tão somente a partir das escolhas pessoais, das preferências e experiências individuais, mas há uma tensão, dado que a dita performance é um fenômeno que parte da dialética entre os sujeitos e a sociedade, sendo constituída nos processos sociais.

É justamente a repetição que resulta a eficiência dos atos performativos e que propicia a base para a constituição de identidades religiosas, como aquelas vinculadas à IEAD. Não obstante, os atos contínuos que destoam das identidades hegemônicas é que possibilitam a subversão da norma e a constituição de novas performances, de novas práticas sociais (Butler, 2003). Essas performances "destoantes" promovem a reflexão de que não há identidade evangélica preexistente pela qual um ato ou tributo possa ser medido; não haveria, portanto, atos verdadeiros ou falsos, reais ou deturpados, e a postulação de uma identidade religiosa verdadeira seria uma ficção reguladora. 
Não falamos aqui, pois, do acatamento massivo das diretrizes colocadas, há também possibilidades de negociação ou resistência por parte dos sujeitos. Inclusive subversão às normas, levando algumas pessoas à condição de corpos dissidentes (Butler 2003). Desde essa perspectiva, nas análises levantadas nessa etnografia, é preciso reiterar que compreendemos aqui a pessoa como sempre inacabada, experiência que se constrói a partir da ideia de "estar no mundo" localizado e corporificado em constante construção.

Em outro dia de observação, notamos que, já na quadra, Marilene e Edna pegaram uma peteca num saco onde outros equipamentos para as aulas de EF ficavam. Feito isso, as estudantes permaneceram todo o horário num canto da quadra, à sombra do pequizeiro e afastada dos demais colegas, que se mobilizavam em vários jogos e atividades coletivas. Questionada sobre o fato de comumente não participar das atividades coletivas, Edna relatou que não gostava de jogar futsal, porque "isso é por falta de costume, coisa de criação, eu não jogava quando era pequena, aqui eu gosto de jogar peteca, lá em casa eu não gosto de brincar".

Nesse mesmo dia Marilene manifestou interesse em brincar com os colegas, o que causou certa surpresa em Edna, que mirou a amiga como quem não estivesse entendendo. Ante esse gesto, Marilene nada disse e entrou no jogo balançando os ombros, como que justificando o comportamento "inesperado". Assim, Edna seguiu sozinha para o seu canto predileto e ora jogava a peteca de um lado para outro sozinha, ora parava e fica observando seus colegas. Não tendo passado muito tempo, Marilene saiu do jogo e voltou para junto de Edna, como era ordinário. Algumas vezes as duas paravam o jogo de peteca, encostavam-se ao alambrado e ficavam olhando os alunos que estavam realizando as atividades. Findada a aula, elas geralmente voltavam juntas para a escola, sem que houvesse alguma conversa com os outros discentes da sala.

Durante as observações, também, foi possível perceber que Kênia quase sempre ficava em um dos cantos da quadra com uma de suas amigas jogando peteca, reservadamente. Relevante considerar que, quando a peteca caía no chão, ela e suas amigas demonstravam relativa dificuldade em flexionar o corpo para pegá-la, talvez devido às saias longas que geralmente usavam ou mesmo ao fato de cuidarem-se, ante as diretrizes religiosas, de não evidenciarem algumas partes do corpo, o que poderia acontecer com o referido movimento. Ante isso, nos demos conta de que elas adaptaram uma maneira de virar as pernas para a direita ou para a esquerda, joelhos e tronco semiflexionados, esticando bem os braços até alcançarem a peteca.

Importante também destacar que a incorporação do habitus não é plenamente consciente por parte dos indivíduos, tampouco está isenta de tensões, crises e possibilidades de mudança, pelo contrário. Ainda que sejam estruturas duradouras, novos habitus vão se constituindo ao longo do tempo de acordo com o contexto sociocultural e o lugar que o sujeito ocupa. Ademais, o habitus de classe ou grupo não nega a diversidade de estilos pessoais, pois, para Bourdieu (1988), essas variantes individuais são "variantes estruturais" pelas quais se revelam as marcas singulares da posição no interior da classe e da trajetória dos sujeitos. Isso significa dizer que o habitus não tem dimensão determinista, rígida, mas que é suscetível de transformações, passível de mudanças no decorrer da trajetória dos grupos ou indivíduos. 
Israel, por exemplo, às vezes participava de alguns esportes coletivos, detidamente futsal e handebol. Nesses jogos, ele fazia grande esforço para acompanhar o ritmo dos colegas, pois, como foi possível depreender da observação de sua movimentação pela quadra, ele não apresentava muito equilíbrio corporal. Ainda que, no entanto, ele mostrasse interesse no jogo, em nenhum dia observamos sua voz clamando pela bola para os colegas da sala. Nos jogos de futsal, por exemplo, ele apenas corria e aproveitava a posse de bola para marcar um gol. Apesar de contido, seu sorriso foi constante durante toda a brincadeira.

Pelo que depreendemos, Silvane tinha um estilo aparentemente mais descolado em relação às outras meninas da Igreja: usava short jeans acima do joelho, cabelo curto amarrado, detinha mais destreza corporal nos jogos, dominava bem a bola e manifestava ter bom equilíbrio. Mariane e Geovana, ao contrário da maioria dos alunos da IEAD, às vezes participavam dos jogos de futsal. As duas, mesmo em dias quentes, costumavam ir para as aulas com uma blusa de frio e capuz, saia jeans, trança nos cabelos e um chinelo de dedo de borracha um tanto gasto que dificultava a corrida. Eram consideradas pelos meninos da aula como as melhores jogadoras de futsal do time das meninas.

A dupla desenvolveu uma tática diferente para o jogo, no qual usavam a saia à altura do joelho para receber a bola, de maneira que ela não passasse pelas suas pernas. Dessa forma conseguiam controlá-la e chutá-la para outra colega de time. Mas, mesmo com as técnicas inventadas, a saia comprida apertada nas pernas claramente limitava seus movimentos, o que não as impedia de marcarem alguns gols. Na comemoração dos gols, Mariane, por exemplo, se continha, apenas levantava o braço como se puxasse uma alavanca invisível e sorria. Outras vezes ela dava pulinhos e um gritinho de alegria, mas sem se aproximar muito dos colegas de time para a devida comemoração.

Chamou-nos a atenção em um dos dias de observação o fato de que alguns alunos estressavam e agrediam verbalmente as meninas que ficavam no canto da quadra jogando peteca ou pulando corda. Segundo os garotos, elas invadiam o campo de jogo. A professora apitou, parou o jogo e disse que, se eles não respeitassem o espaço das meninas, ela diminuiria a duração do jogo para que só elas usassem a quadra no restante do tempo. A respeito do ocorrido, Marilene comentou:

Nas aulas de Educação Física é assim, quando vamos jogar bola, primeiro quem joga são os garotos. Enquanto nós, meninas, ficamos conversando ou brincando de corda ou peteca e depois deles a gente vai jogar também. Eles não gostam de nós meninas jogarmos bola, é para que assim a quadra fique livre para eles.

Partindo da premissa de que os corpos e os comportamentos são socialmente aprendidos e reconstruídos histórica e socialmente, podemos problematizar as diferenças nas atitudes corporais das e dos estudantes em relação às regras de disciplina do corpo, movimentação e hierarquização dos espaços a partir do gênero dos sujeitos.

Butler (2003) afirma que, em sua materialização em qualquer cultura, os corpos, para serem inteligíveis, precisam fazer sentido em determinada sociedade, ou seja, precisam ser reconhecidos dentro de dada matriz cultural. A primeira e principal marca, segundo a autora, está na inscrição semântica de gênero que antepõe masculino e feminino. Assim, os sujeitos se constroem como corpos masculi- 
nos e femininos a partir de diversas tecnologias, discursos institucionalizados e práticas cotidianas na expectativa de manter o gênero em sua estrutura binária que tem sua base assentada na ideologia da heterossexualidade (Butler, 2003; De Laurentis, 1994). Vão sendo demarcadas características corporais a partir do gênero dos sujeitos, outorgando direcionamento nas percepções, ações e usos do corpo em várias perspectivas. Em um processo sócio-histórico, os corpos vão assumindo características que as sociedades lhes consagraram ao longo do tempo, organizando o mundo de forma dual, dividindo-o em masculino e feminino, de maneira hierarquizada, inclusive dentro das mesmas categorias (Vale de Almeida, 1996).

O gênero está diretamente ligado ao corpo, o que significa dizer que a performance de gênero está relacionada a estilos corporais, estando estes submetidos a um sistema de dominação patriarcal (Butler, 2003). O corpo, pois, é pensado como uma "superfície politicamente regulada", constituída histórica e socialmente. Nessa perspectiva, o gênero, então, faz parte do mapa cognitivo com que os sujeitos operam, não sendo, entretanto, uma estrutura sólida, duradoura, intrínseca ao indivíduo; é construído socialmente ao longo do tempo por meio da incorporação, pelos sujeitos, de gestos, movimentos, práticas, disposições corporais masculinas e femininas, regras e estilos, perpassado e influenciado consecutivamente pelas expectativas sociais de cada contexto histórico e social.

Assim, retomando a fala de Marilene sobre a divisão do espaço da quadra "destinado" a meninas e a meninos, é preciso retomar, ainda que brevemente, que entre homens e mulheres durante muito tempo ela se assentou na biologia. $\mathrm{O}$ argumento central desse discurso era, em uma ótica essencialista, que as diferenças sexuais se ligavam às funções e capacidades de cada sexo, sendo que aos homens, considerados superiores, cabiam as tarefas mais importantes, tal como o papel de provedor da família, enquanto que às mulheres eram conferidos os cuidados dos filhos e permanência no espaço privado do lar (Rosaldo, 1979). A esse respeito, Laqueur (2001) enfatiza que a criação da esfera pública burguesa suscitou grandes discussões sobre qual(is) sexo(s) deveria(m) ocupá-la legitimamente. Nesse ínterim, a biologia apareceu muitas vezes como justificativa para "resguardar" a mulher no espaço privado do lar, uma vez que se considerava, entre outros argumentos de natureza semelhante, que a menstruação era elemento desfavorável para a participação das mulheres nas atividades públicas.

Quanto às atividades corporais, Goellner (2003) preleciona que, aquelas vislumbradas como mais intensas, como lutas e esportes, por exemplo, não eram recomendadas às mulheres em virtude de sua suposta natureza mais frágil em relação ao homem. Essa perspectiva era pautada em explicações biológicas, mais especificamente na fragilidade dos órgãos reprodutivos e na necessidade de sua preservação para uma maternidade sadia.

A fim de trazer essa discussão para a contemporaneidade, cabe destacar a investigação de Thorne (1993) sobre as relações de gênero construídas entre crianças e adolescentes em duas escolas norte-americanas nos anos de 1976, 1977 e 1980: o gênero era a categoria que tinha mais relevo nesses ambientes, manifestado por meio da divisão de espaços e tempos reservados para as brincadeiras de meninos e meninas. Os meninos, de modo geral, ocupavam grandes áreas para jogos coletivos, enquanto as meninas ficavam com espaços pequenos. As brincadeiras de meninos e meninas costumavam ser separadas, e um grupo respeitava o espaço do outro sem questionar. Brincar de atividades próprias do gênero oposto geralmente não era permitido pelas crianças. 
Em sua pesquisa acerca das marcas da educação evangélica no corpo feminino, Rigoni e Prodócimo (2013) manifestam que as preocupações que os fiéis da IEAD têm com a alma, cujo peso recai ainda mais sobre o corpo feminino em comparação ao masculino no que se refere à vigilância e controle e, obviamente quanto aos espaços a ele destinado - acrescentamos -, teriam como motivo principal evitar que caia e seja motivação de pecado para os homens, visto que poderia provocar sentimentos menos "dignos". Assim sendo, o controle sobre o corpo das mulheres deve fixar-se tanto em sua aparência, por meio da constituição de um corpo discreto, que deve evitar maquiagens, adornos e cores chamativas; bem como nos gestos e comportamentos levados a cabo na igreja, na escola e outros espaços.

Nas falas e observações do cotidiano nas aulas de Educação Física das meninas que compõem esta pesquisa, pudemos notar que as marcas da religião impõem, em maior ou menor grau para cada uma delas, modos de perceber e vivenciar o corpo que geralmente obstaculizam uma experiência motora e estética mais livres nessas aulas, em comparação aos meninos, de modo geral, e às meninas que não pertencem à IEAD.

Se as meninas investigadas não têm uma visão de si e modos de comportar-se uniformes, o que é de se esperar, é possível afirmar pelo que pudemos depreender, que elas, de maneira geral, apresentam modos de vestir-se e comportar-se com alguma similaridade entre elas nas aulas de EF, como por exemplo, o uso de saias que impedem alguns movimentos, o cuidado com a visibilidade de seu corpo pelos outros ao se movimentarem, como ao abaixarem para pegar uma bola ou mesmo ao sentarem-se no chão. Ademais, fica evidente que a busca pelos espaços que circundam a quadra se trata de uma estratégia de manterem-se afastadas de algumas atividades propostas nas aulas, as quais podem ser vistas como inadequadas em sua cosmologia religiosa.

Isso posto, é fato que muitas mudanças ocorreram desde então, mas é indiscutível que o corpo e seu trânsito continuam sendo perpassados na medida em que ele é constantemente marcado pelas mais diversas pedagogias. É objeto de controle, consumo e hábitos rotineiros que vão, pouco a pouco, adestrando-o por meio de um poder que se inscreve no cotidiano e contribui para a construção das vivências corporais dos sujeitos.

\section{Considerações finais}

Primeiramente, reiteramos a importância de a escola, no cumprimento de sua função social, que, além de ensinar é também socializar, conhecer seus alunos como sujeitos concretos "em carne, osso e sangue”, parafraseando Malinowski, e em suas alteridades. Para isso, faz-se necessário investimento em pesquisas que tematizem o fenômeno religioso nas múltiplas dimensões em que está integrado, como uma expressão simbólica e material potente na compreensão da instituição e de seus sujeitos na cultura rural, abordando, particularmente, jovens alunos em contextos pedagógicos.

Como dito antes, esse é um recorte pouco investigado e que provoca inúmeras reflexões. Fica, assim, o convite para que este artigo estimule pesquisadores a enfrentar os desafios de compreenderem e visibilizarem escolas pobres no urbano e no rural, imersas numa conjuntura de desigualdade, diferença e diversidade, que marcam e configuram fortemente a sociedade brasileira.

Num cenário entre a desigualdade histórica e, ao mesmo tempo e paradoxalmente, a evidência espetacular (Baudrillard, 1991) que tenta colocar a todos numa mesma vitrine virtual, os adolescentes 
e jovens da escola que pesquisamos, na articulação entre o subjetivo e social, constroem-se performaticamente como corpo marcado por uma lógica religiosa, entre outras esferas e processos sociais. Que ocorrem por meio da incorporação de rasgos da IEAD ancorados em uma estrutura de recompensas e castigos. Têm como espaço-tempo, a partir de e no qual incorporam marcas socioculturais que comunicam significados e simbologias que possibilitam sua distinção como corpo de um fiel.

Desde essa perspectiva, é necessário considerar o fato de que, em sua materialização em qualquer cultura, os corpos carecem de produção, inscrição e reconhecimento de marcas de um contexto próprio para que possam existir, isto é, para que sejam inteligíveis, eles precisam fazer sentido em determinada sociedade (Butler, 2003). Assim, os meninos e meninas da pesquisa constituem-se como sujeitos encarnados (Merleau-Ponty, 1994) pelos/nos caminhos por eles(as) enveredados, nas relações que mantêm com os pais, irmãos, membros da congregação religiosa da qual fazem parte, bem como professores, amigos, entre outros sujeitos. Dessa forma, os alunos têm suas ações impregnadas de regras sociais que vão se internalizando na convivência em sociedade, no caso, especialmente, via religião, mas não só, cujas regras e informações normatizadoras são naturalizadas por eles em formato de normas, convenções, tabus e costumes, fazendo com que tenham suas interações orientadas por elas.

Pelo que pudemos depreender da etnografia, se alguns dos estudantes flexibilizavam em alguma medida algumas regras e preceitos da IEAD a partir de seu entendimento da religiáo e comportamentos pessoais, destacamos que as possíveis rupturas acontecem em intensidade e modos diferentes de um para outro, levando em conta que o corpo é sempre um produto cultural não acabado, estando em contínua construção. Em outras palavras, a estética corporal dos alunos, do modo como é por cada um experimentada, passa pelos desafios de romper com barreiras individuais que cada um carrega em si, devido a sua subjetividade e experiências, como também pelo social, na direção do que propõe Mauss, entre outros, que ressaltam as normatizações sociais que tentam moldar o corpo, em culturas distintas, por meio de sistemas de classificação.

Sandra Pereira Tosta é Doutora em Ciência Social (Antropologia Social) pela Universidade de São Paulo (USP) e Professora Visitante do Programa de Pós-graduação em Educação da Universidade Federal de Ouro Preto (UFOP).

Weslei Lopes da Silva é Doutor em Ciências Sociais pela Pontifícia Universidade Católica de Minas Gerais (PUC-Minas) e Professor da Universidade Estadual de Minas Gerais (UEMG).

Lucimara Aparecida Lima Costa é Mestra em Educação pela Pontifícia Universidade Católica de Minas Gerais (PUC-Minas), professora da Rede Estadual de Educação de MG e supervisora da Rede Municipal de Educação de Capelinha $(M G)$. 


\section{REFERÊNCIAS}

Baudrillard, J. (1991). Simulacros e simulação. Lisboa: Relógio D’Agua.

Butler, J. (2003). Problemas de gênero: feminismo e subversão da identidade. Rio de Janeiro: Civilização Brasileira.

Clifford, J. (2002). A experiência etnográfica: antropologia e literatura no século XX. Rio de Janeiro: UFRJ.

Dauster, T.; Tosta, S. P.; Rocha, G. (orgs.). (2012). Etnografia e educação. Rio de Janeiro: Lamparina.

De Lauretis, T. (1994). A tecnologia de gênero. In: H. B. Holanda (org.). Tendências e impasses: o feminismo como crítica cultural. Rio de Janeiro: Rocco.

Feixa, C. (2014).De la generacion@a la \#generacion. Barcelona: Ariel.

Goldenberg, M. (2006). O corpo como capital: para compreender a cultura brasileira. Arquivos e Movimento, 12(2), 115-123. Disponível em: https://revistas.ufrj.br/index.php/am/article/view/9083.

Gonçalves, J. R. (2002). Apresentação. In: J. Clifford. A experiência etnográfica: antropologia e literatura no século $X X$ (pp. 7-16). Rio de Janeiro: Ed. UFRJ.

Instituto Brasileiro de Geografia e Estatística. População residente, segundo a religião - 2010. Resultados gerais da amostra - Tabela 1489 com números reais adaptados com o acréscimo da percentagem. Disponível em: http://downloads.ibge.gov.br/downloads_estatisticas.htm. Acesso em: 01 nov. 2014.

Köhler, C. (1996). História do vestuário. São Paulo: Martins Fontes.

Laqueur, T. (2001). Inventando o sexo: corpo e gênero dos gregos a Freud. Rio de Janeiro: Relume-Dumará.

Le Breton, D. (2011). Antropologia do corpo e modernidade. Petrópolis, Rio de Janeiro: Vozes.

Magnani, J. G. C \& Souza, B. M. (org.). (2007). Jovens na metrópole: etnografias de circuitos de lazer, encontro e sociabilidade. São Paulo: Terceiro Nome.

Maia, C. L. (2010). Cartografias juvenis: mudanças e permanências nos territórios e modos de ser jovem (Tese de Doutorado). Faculdade de Educação, Universidade Federal de Minas Gerais, Belo Horizonte. Disponível em: http://hdl.handle.net/1843/BUOS-8FNQE4

Malinowski, B. (1984). Argonautas do Pacifico Ocidental. São Paulo: Abril.

Mariano, R. (2004). Expansão pentecostal no Brasil: o caso da Igreja Universal do Reino de Deus. Estudos Avançados, 18(52), 121-138. https://doi.org/10.1590/S0103-40142004000300010 
Mauss, M. (1974). Sociologia e Antropologia. São Paulo: Edusp.

Merleau-Ponty, M. (1994). Fenomenologia da percep̧̧ão. São Paulo: Martins Fontes.

Najmanovich, D. (2002). Pensar/viver a corporalidade para além do dualismo. In: R. L. Garcia (org.). O corpo que fala dentro e fora da escola. Rio de Janeiro: DP\&A.

Novaes, R. et al. (2016). Juventude, religiosidade, territórios e redes: reflexões sobre resultados de pesquisas. In: Agenda Juventude Brasil: leituras sobre uma década de mudanças (pp. 233-263). Rio de Janeiro: Unirio. Disponível em: https://bibliotecadigital.mdh.gov.br/jspui/handle/192/133

Oliveira, R. C. (2006). O trabalho do antropólogo. 2a ed. São Paulo: Paralelo 15/Unesp.

Peirano, M. (2019). A eterna juventude da antropologia: etnografia e teoria vivida. In: R. Guber (coord.). Trabajo de campo en América Latina: experiencias antropológicas regionales en etnografía. (pp. 169-181). Bogotá : Campus editorial/Sb editorial.

Pereira, A. B. (2018). Um rolê pela cidade de riscos. São Carlos: EdUFSCAR.

Rigoni, A. C. C. \& Prodócimo, E. (2013). Corpo e religião: marcas da educação evangélica no corpo feminino. Revista Brasileira Ciências do Esporte, 35(1), 227-243. https://doi.org/10.1590/S010132892013000100017

Rosaldo, M. (1979). A mulher, a cultura e a sociedade: uma revisão teórica. In: M. Rosaldo \& L. Lamphere (coords.). A mulher, a cultura e a sociedade (pp. 33-64). Rio de Janeiro: Paz e Terra.

Sposito, M. P.; Souza, R. \& Silva, F. A. (2018). A pesquisa sobre jovens no Brasil: traçando novos desafios a partir de dados quantitativos. Educação e Pesquisa, 44:e170308. Epub 21 dez. 2017. http:// dx.doi.org/10.1590/s1678-4634201712170308

Tosta, S. P et al. (2016). Culturas urbanas: georreferenciamento e análise cultural de grupos juvenis em sua relação com a escola e com a cidade de Belo Horizonte/MG. Territórios de cultura: educação, arte e tecnologia na cidade de Belo Horizonte MG/Brasil. Relatório Técnico Científico. Belo Horizonte: PUC Minas; CNPq.

Tosta, S. P. \& Diniz, A. (2020). Territórios de cultura: Educação, arte e tecnologia na cidade de Belo Horizonte MG/ Brasil. Belo Horizonte: PUC Minas. Disponível em: https://www.editora.pucminas.br/obra/territorios-de-cultura-educacao-arte-e-tecnologia-na-cidade-de-belo-horizonte-mg-brasil-pdf

Vale de Almeida, M. (1996). Corpo presente: treze reflexões antropológicas sobre o corpo. Portugal: Etnográfica Press.

Vieira, R. (2003). Vidas revividas: etnografia, biografias e a descoberta de novos sentidos. In: T. H. Caria (org.). Experiência etnográfica em Ciências Sociais (pp. 76-96). Porto: Edições Afrontamento. 


\title{
RELIGIÃO E PERFORMANCES CORPORAIS: ETNOGRAFIA COM ALUNOS EVAN- GÉlicos DA ZONA RURAL DE UMA ESCOLA PÚBLICA DE MINAS GERAIS
}

Resumo: Este artigo tem como objetivo apreender, compreender e interpretar, por meio de uma etnografia numa escola estadual da zona rural de Minas Novas-MG, como um grupo de jovens alunos, cujo pertencimento religioso era pela Igreja Evangélica Assembleia de Deus, pensam e reagem às alteridades que carregam e visibilizam no ambiente escolar, por meio, sobretudo, de suas performances corporais nas aulas de Educação Física. Para isso, foram utilizados observação participante, caderno de campo, inclusive pelos alunos, entrevistas e depoimentos orais. $\mathrm{O}$ resultado revelou que eles se constroem como corpo marcado por uma lógica religiosa na articulação entre o subjetivo e o social. Alguns dos estudantes flexibilizam algumas regras e comportamentos pessoais, outros incorporam com mais intensidade marcas socioculturais que comunicam significados e simbologias que possibilitam sua distinção como fiel.

Palavras-chave: Etnografia; Escola rural; Aluno evangélico; Performance corporal.

\section{RELIGION AND BODY PERFORMANCE: ETHNOGRAPHY WITH EVANGELICAL STUDENTS FROM THE RURAL AREA OF A PUBLIC SCHOOL IN MINAS GERAIS}

\begin{abstract}
This article aims to apprehend, understand, and interpret, through an ethnography in a state school in the rural area of Minas Novas-MG, Brazil, how a group of young students, whose religious belonging was by the Evangelical Church Assembly of God, think and react to otherness that they carry and make visible in the school environment through their corporal performances in physical education classes. For that, participant observation, field notebook, including by the students, interviews, and oral testimonies were used. The result revealed that they construct themselves as a body marked by a religious logic between subjective and social. Some of the students make some rules and personal behavior more flexible, others more intensely incorporate socio-cultural marks that communicate meanings and symbologies that enable their distinction as faithful.
\end{abstract}

Keywords: Ethnography; Rural school; Evangelical student; Body performance.

RECEBIDO: $30 / 05 / 2020$

APROVADO: $27 / 02 / 2021$ 